\title{
ANALISIS PEMASARAN DAN STRATEGI PENGEMBANGAN USAHATANI UBI KAYU DI KELURAHAN BALAI RAJA KECAMATAN PINGGIR KABUPATEN BENGKALIS PROVINSI RIAU
}

\section{Marketing Analysis and Cassava Farming Business Development Strategy in Balai Raja Village, Pinggir District, Bengkalis Regency, Riau Province}

\author{
Rian Saputra, Fahrial \\ Prodi Agribisnis, Universitas Islam Riau \\ email: Fahrial2018@agr.uir.ac.id \\ [Diterima: November 2021; Disetujui: Desember 2021]
}

\begin{abstract}
Balai Raja Village is one of the centers of cassava production in Pinggir District of Bengkalis Regency in Riau Province with production of 35 tons/ha. This research aims to find out and analyze the characteristics of farmers and traders of cassava, the marketing channels and institutions, marketing costs, marketing margin, marketing profits, farmer's share, and marketing efficiency of cassava farm business, and the cassava farming business development strategy. This study was used survey method during for 6 (six) months from July to December 2020. The results showed that the farmers was still productive life, the level of education of farmers was relatively low, namely junior high school graduation, the average length of experience was 4 years, and the number of farmers' families was 3 people. The average age of cassava traders was still productive life, the level of education of trader was relatively high, namely high school graduation, the average experience was 5 years, and the number of family member was 3 people. The marketing channel had only 1 marketing channel, namely farmer-trader - tapioca factory. Marketing cost was IDR 155/kg, marketing margin was IDR $200 / \mathrm{kg}$, marketing net margin was IDR $45 / \mathrm{kg}$, farmer's share was $75 \%$. Marketing efficiency was $19.37 \%$. The results of the analysis of the cassava farming business development strategy in the village of Pinggir district of Bengkalis Regency was in quadrant 1, namely the S-O. The alternative strategy obtained was based on the S-O strategy, namely the availability of land and skilled labor. It can meet the increasing demand for cassava production. By using superior wood seedlings and government support in providing extension, it can be expanded due to the development of cassava processing industry.
\end{abstract}

Keywords: Cassava, Marketing, Development Strategy.

\begin{abstract}
ABSTRAK
Kelurahan Balai Raja merupakan salah satu sentral produksi ubi kayu di Kecamatan Pinggir Kabupaten Bengkalis Provinsi Riau karena menghasilkan produksi ubi kayu yang besar yaitu 35 ton/Ha. Penelitian ini bertujuan untuk mengetahui dan menganalisis karakteristik petani dan pedagang ubi kayu, saluran dan lembaga pemasaran, biaya pemasaran, margin pemasaran, keuntungan pemasaran, farmer's share, dan efisiensi pemasaran usaha tani ubi kayu dan strategi pengembangan usaha tani ubi kayu. Penelitian ini menggunakan metode survey waktu penelitian ini selama 6 (enam) bulan mulai bulan Juli sampai dengan Desember 2020. Hasil penelitian menunjukkan bahwa rata-rata umur petani ubi kayu masih produktif, tingkat pendidikan petani rata-rata tergolong rendah yaitu tamatan SMP, rata-rata lama pengalaman berusaha tani 4 tahun, dan jumlah tanggungan keluarga petani 3 jiwa. Rata-rata umur pedagang ubi kayu masih produktif, tingkat pendidikan pedagang ratarata tergolong tinggi yaitu tamatan SMA, lama pengalaman berdagang rata-rata 5 tahun, dan jumlah tanggungan keluarga pedagang rata-rata 3 jiwa. Saluran pemasaran terdapat hanya 1 saluran pemasaran. Yaitu: Petani-Pedagang - Pabrik Tapioka. Biaya pemasaran Rp 155/kg, Marjin pemasaran Rp 200/Kg, Keuntungan Pemasaran Rp 45/Kg, Farmer's share 75\%. Efisiensi Pemasaran 19,37\%. Hasil analisis strategi pengembangan usaha tani ubi kayu di Kelurahan Balai Raja Kecamatan Pinggir Kabupaten Bengkalis berada pada kuadran 1, yaitu strategi S-O. Alternati strategi yang diperoleh
\end{abstract}


berdasarkan strategi S-O yaitu tersedianya lahan dan tenaga kerja yang mahir, maka bisa memenuhi permintaan produksi ubi kayu yang meningkat, dengan menggunakan bibit kayu unggul dan dukungan pemerintah dalam memberikan penyuluhan maka bisa dilakukan perluasan pasar karena adanya perkembangan industri pengolahan ubi kayu.

Kata kunci: Ubi Kayu, Pemasaran, Strategi Pengembangan

\section{PENDAHULUAN}

Indonesia merupakan negara yang akan kaya sumber daya alam. Salah satu sumbr daya alam yang banyak berada di Indonesia dalah ubi kayu. Ubi kayu merupakan tanaman yang dapat digunakan sebagai bahan pangan, pakan, sumber energi, dan berbagai macam keperluan industri (Islami, 2015). Menurut (Hafsah, 2003) sebagian besarnya produksi ubi kayu di indonesia digunakan untuk memenuhi kebutuhan dalam negeri (85-90 persen), namun sisanya diekspor dalam bentuk chips, gaplek serta tepung tapioka. Untuk di Provinsi Riau tanaman ubi kayu cukup bagus dan baik untuk dikembangkan sebagai penunjang pembangunan sektor pertanian dan meningkatkan produksi secara berkesinambungan, baik untuk memenuhi konsumsi masyarakat ataupun untuk memenuhi kebutuhan bahan baku industri. Sebab di Provinsi Riau tanaman ubi kayu sangat cocok untuk di usahakan karena kondisi tanahnya yang mendukung, dari data Dinas Tanaman Pangan dan Hortikultara Provinsi Riau Pada tahun 2018 produktivitas ubi kayu rata-rata mencapai 30 ton/ha (Dinas Tanaman Pangan dan Hortikultura Provinsi Riau 2019).

Dari penjelasan diatas bahwa di Provinsi Riau produktivitas ubi kayu yang mencapai 30 ton/ha bisa menjadi peluang usaha untuk maju akan lebih baik dan menambah lapangan pekerjaan. Namun permasalahan yang di hadapi saat ini yaitu ketersediaan lahan yang semakin berkurang disebabkan banyaknya lahan beralih fungsi, seperti di Kota Pekanbaru saat ini lahan untuk tanaman ubi kayu setiap tahun semakin berkurang sebab dijadikan untuk lahan perumahan

Kabupaten Bengkalis merupakan daerah produksi ubi kayu paling besar di Provinsi Riau dengan produksi penghasilan mencapai 17.927,4 ton pada tahun 2018. Dengan tingginya produksi ubi kayu yang di hasilkan di daerah tersebut maka bisa menunjang perekonomian petani ubi kayu di daerah tersebut. Kelurahan Balai Raja merupakan salah satu sentral produksi ubi kayu di Kecamatan Pinggir Kabupaten Bengkalis Provinsi Riau karena menghasilkan produksi ubi kayu yang besar, meskipun usaha ubi kayu yang dilakukan petani sebagian hanya usaha sampingan karena dominan lebih kepada usaha kelapa sawit namun kondisi tanahnya sangat cocok untuk usaha ubi kayu. Berikut data perkembangan mengenai produksi luas tanam ubi kayu di Kecamatan Pinggir Kabupaten Bengkalis tahun 2019. Hal ini dapat dilihat pada tabel 1 di bawah ini :

Tabel 1. Luas Tanam, Produksi, Produktivitas Ubi Kayu di Kecamatan Pinggir Kabupaten Bengkalis Tahun 2019.

\begin{tabular}{clrrr}
\hline \multirow{2}{*}{ No } & \multicolumn{1}{c}{ Desa/Kelurahan } & $\begin{array}{c}\text { Luas Tanam } \\
(\mathrm{Ha})\end{array}$ & $\begin{array}{c}\text { Produksi } \\
(\text { Ton })\end{array}$ & $\begin{array}{c}\text { Produktivitas } \\
\text { (Ton) }\end{array}$ \\
\hline 1 & Pinggir & 7 & 12,6 & 1,8 \\
2 & Semunai & 3 & 54 & 18 \\
3 & Tengganau & 16 & 288 & 18 \\
4 & Balai pungut & 5 & 60 & 12 \\
5 & Muara basung & 2 & 30 & 15 \\
6 & Kelurahan Titian antui & 10 & 350 & 35 \\
$\mathbf{7}$ & Kelurahan Balai raja & $\mathbf{2 5 6}$ & $\mathbf{8 . 9 6 0}$ & $\mathbf{3 5}$ \\
8 & Sungai meranti & 4 & 7,2 & 1,8 \\
9 & Pangkalan libut & 10 & 15,2 & 1,8 \\
10 & Buluh apo & 7 & 12,6 & 1,8 \\
\hline \multicolumn{2}{c}{ Jumlah } & 320 & $9.789,6$ & 140,2 \\
\hline
\end{tabular}

Sumber : Balai Penyuluhan Pertanian Kecamatan Pinggir Tahun 2020 
Dari tabel 1 diatas dapat di simpulkan bahwa kelurahan Balai Raja merupakan penghasil ubi kayu paling besar di kecamatan Pinggir dibandingkan dengan desa lain di kecamatan Pinggir dengan luas tanam $256 \mathrm{Ha}$, dengan menghasilkan produksi 35 ton/Ha dengan jumlah keseluruhan 8.960 ton pada tahun 2019. Dengan demikian Kelurahan Balai Raja sangat cocok untuk melakukan pengembangan usaha tani ubi kayu dengan kondisi tanah yang cocok sekaligus mendukung sebagai sentral ubi kayu di Kecamatan Pinggir tersebut.

Pemasaran merupakan hal yang penting dalam menjalankan usaha pertanian karena pemasaran merupakan tindakan ekonomi yang berpengaruh terhadap tinggi rendahnya pendapatan petani. produksi yang banyak akan sia-sia karena harga pasar yang rendah. karena itu tingginya produksi tidak mutlak memberikan hasil atau keuntungan tinggi tanpa disertai pemasaran yang baik dan efisien (Kotler, 1992).

Lembaga pemasaran yaitu termasuk produsen, tengkulak, pedagang pengumpul, importir, eksportir maupun sebagainya itu akan sangat diperlukan. Jika proses pemasaran tersebut berjalan dengan sempurna, maka segala pihak yang terkait dapat diuntungkan (Soekartawi, 2003).

Adapun permasalahan yang terjadi di Kelurahan Balai Raja terkait tentang pemasaran yaitu terbatasnya petani dan pedagang dalam memasarkan ubi kayu disebabkan terbatasnya industri ubi kayu dalam pembelian ubi kayu sehingga harga ubi kayu menjadi turun dan tidak stabil sedangkan untuk pengembangan usaha dari ubi kayu tersebut petani dan pedagang hanya menjual ubi kayu masih dalam bentuk ubi kayu utuh, tujuan dalam penelitian ini diantaranya :

1. Karakteristik Petani dan Pedagang Ubi Kayu di Kelurahan Balai Raja Kecamatan Pinggir tersebut.

2. Saluran dan lembaga Pemasaran, Biaya Pemasaran, Margin Pemasaran, Keuntungan Pemasaran, Farmer Share, dan Efisiensi Pemasaran Usaha Tani Ubi Kayu di Kelurahan Balai Raja Kecamatan Pinggir tersebut.

3. Strategi Pengembangan Usaha Tani Ubi Kayu di Kelurahan Balai Raja Kecamatan Pinggir tersebut.

\section{METODE PENELITIAN}

\section{Metode dan Tempat Penelitian}

Metode yang digunakan dalam penelitian ini adalah metode survey. Penelitian ini dilakukan di Kelurahan Balai Raja Kecamatan Pinggir Kabupaten Bengkalis Provinsi Riau. Pemilihan lokasi dilakukan secara sengaja (purposive) dengan berdasarkan pertimbngan bahwa di Kelurahan Balai Raja Kecamatan Pinggir Kabupaten Bengkalis memiliki potensi produksi ubi kayu yang cukup besar sehingga memiliki peluang yang besar untuk dapat dikembangkan untuk masa mendatang. Pertimbangan lainnya yaitu adanya ketersediaan data yang diperlukan dalam penelitian ini serta petani dan pedagang sebagai objek untuk penelitian.

Data sekunder diperoleh dari literatur oleh berbagai lembaga/instansi diantaranya Dinas Tanaman Pangan dan Hortikultura, Balai Penyuluhan Pertanian Kecamatan, hasil penelitian terdahulu ataupun sumber pustaka yang relevan.dari BPS seperti: keadaan geografis daerah penelitian, jumlah penduduk, tingkat pendidikan penduduk, dan kedaan sosial ekonomi penduduk setempat.

\section{Analisis Data}

Dalam penelitian ini metode analisis data yang digunakan adalah deskriptif kualitatif dan kuantitatif. Analaisis deskriptif kualitatif menganalisis saluran pemasara, biaya pemasaran, margin pemasaran, Keuntungan Pemasaran Farmer's Share, Efesiensi Pemasaran, Analisis Matriks IFE dan EFE, Analisis SWOT.

\section{Analisis Karakteristik Petani dan Pedagang Ubi Kayu.}

Karakteristik petani dan pedagang dapat diamati dari beberapa variabel yang memungkinkan memberikan gambaran tentang pengelolaan usaha. Karakteristik petani dan pedagang meliputi : umur, tingkat pendidikan, pengalaman berusaha, dan jumlah tanggungan keluarga. Dengan menggunakan analisis deskriptif kualitatif dari hasil wawancara dilapangan mengunakan kuesioner yang telah disediakan.

\section{Saluran pemasaran}

Saluran pemasaran Ubi Kayu di Kelurahan Balai Raja Kecamatan Pinggir Kabupaten Bengkalis dapat dianalisis dengan menelusuri kegiatan pemasaran mulai dari petani sampai pabrik pengolahan atau 
konsumen akhir sehingga akan membentuk pola saluran pemasaran yang terjadi dan jumlah lembaga yang terlibat.

\section{Biaya Pemasaran}

Biaya pemasaran adalah biaya yang dikeluarkan untuk keperluan pemasaran. Menghitung besarnya biaya pemasaran dapat menggunakan rumus menurut Soekartawi (2000):

$$
\begin{aligned}
& \mathrm{Bp}=\sum_{i}^{n}={ }_{1} \mathrm{Bi} \ldots \ldots . \\
& \mathrm{Bp}=B^{1}+B^{2}+B^{3} .
\end{aligned}
$$

Keterangan:

$\mathrm{Bp}=$ Biaya Pemasaran $(\mathrm{Rp} / \mathrm{kg})$

$\mathrm{B}^{1}=$ Biaya Transportasi $(\mathrm{Rp} / \mathrm{kg})$

$\mathrm{B}^{2}$ = Biaya Bongkar Muar (Rp/kg)

$\mathrm{B}^{3}=$ Biaya Timbang Rp/kg)

\section{Margin Pemasaran}

Marjin Pemasaran merupakan perbedaan harga yang diterima oleh petani dengan harga yang dibayarkan oleh konsumen. Untuk menganalisis pemasaran data harga yang digunakan adalah harga tingkat petani (produsen) dan harga tingkat konsumen, secara sistematis dapat dirumuskan sebagai berikut:

$\mathrm{Mp}=\operatorname{Pr}-\mathrm{Pf}$

Keterangan :

$\mathrm{Mp}$ : Marjin Pemasaran Ubi Kayu (Rp/kg)

Pr : Harga Ubi Kayu di tingkat konsumen $(\mathrm{Rp} / \mathrm{kg})$

Pf : Harga Ubi Kayu di tingkat produsen $(\mathrm{Rp} / \mathrm{kg})$

Marjin Pemasaran merupakan

penjumlahan yang diperoleh pedagang perantara terdiri dari sejumlah biaya pemasaran yang dikeluarkan dan keuntungan yang diterima oleh pedagang perantara, dirumuskan :

$\mathrm{Mp}=\mathrm{Bp}+\mathrm{Kp}$

Keterangan :

Mp :Marjin Pemasaran Ubi Kayu (Rp/kg)

$\mathrm{Bp}$ :Biaya pemasaran Ubi Kayu (Rp/kg)

$\mathrm{Kp}$ :Keuntungan pemasaran Ubi Kayu $(\mathrm{Rp} / \mathrm{kg})$

\section{Keuntungan Pemasaran}

Menurut Iskandar (2008), keuntungan pemasaran merupakan selisih antara margin pemasaran dengan biaya pemasaran atau dirumuskan dengan:

$\pi=\mathrm{M}-\mathrm{B}$
Keterangan:

$\pi \quad=$ Keuntungan Pemasaran $(\mathrm{Rp} / \mathrm{kg})$

$\mathrm{M}=$ Margin Pemasaran $(\mathrm{Rp} / \mathrm{kg})$

$\mathrm{B}=$ Biaya Pemasaran $(\mathrm{Rp} / \mathrm{kg})$

\section{Famer's Share}

farmer share merupakan perbedaan antara harga ditingkat retail untuk produk pangan dan serat dengan marjin pemasaran ini merupakan porsi dari nilai yang dibayar konsumen akhir yang diterima petani dalam bentuk persentase (\%) (Asmarantaka 2012). Jika total marjinya tinggi bagian yang diterima petani dapat diketahui dengan membandingkan antara harga jual petani dan harga jual ke konsumen akhir atau sering disebut farmer share secara matematis ditulis sebagai berikut :

$F S=\frac{P f}{P r} \times 100 \%$

Keterangan :

Fs : Bagian harga Ubi Kayu yang diterima petani (produsen)

Pf : Harga Ubi Kayu di tingkat petani (produsen)

Pr : Harga Ubi Kayu di tingkat konsumen Jika besarnya bagian yang diterima produsen > 50\%, maka dapat disimpulkan bahwa pemasaran yang terjadi tergolong efisien. Namun apabila besarnya bagian yang diterima produsen $<50 \%$. maka pemasaran yang terjadi belum tergolong efisien.

\section{Efesiensi Pemasaran (EP)}

Efisiensi saluran pemasaran adalah ratio atau perbandingan antara total nilai pemasaran dengan nilai produk yang dipasarkan. Nilai efisiensi pemasaran ini dilihat dengan membandingkan nilai efisiensi pemasaran tiaptiap saluran pemasaran. Dengan rumus sebagai berikut :

$E P=\frac{B P}{N P} X 100 \%$

Keterangan :

EP : Efisiensi pemasaran (\%)

BP : Total biaya pemasaran (Rp)

$\mathrm{NP}$ : Total nilai produk yang dipasarkan (Rp)

Kriteria :

- EP sebesar 0-50\% maka saluran pemasaran efisiensi

- EP lebih besar dari 50\% maka saluran pemasaran kurang efisien

Apabila nilai EP suatu saluran pemasaran lebih kecil dari nilai EP saluran pemasaran lainnya, maka saluran pemasaran 
tersebut dikatakan memiliki efisiensi pemasaran yang lebih tinggi dari pada saluran pemasaran lainnya.

\section{Strategi Pengembangan Usaha Ubi Kayu Analisi Matriks IFE dan EFE}

Matriks IFE (Internal Factor Evaluation) digunakan untuk mengidentifikasi dan mengevaluasi faktor-faktor internal yang menjadi kekuatan dan kelemahan pada pengembangan usaha ubi kayu seperti SDM, lokasi usaha, pemasaran, produksi, manajemen dan keuangan.

Matriks EFE (Eksternal Factor Evaluation) berfungsi untuk mengidentifikasi dan mengevaluasi yang mampu menjadi peluang bahkan ancaman bagi pengembangan usaha ubi kayu. Faktor eksternal yang dianalisis yaitu teknologi, pasar, pesaing, dan kondisi alam.

Langkah-langkah penentuan faktor strategi internal (IFAS) (Wheelen dan Hunger, 2004) adalah:

a. Menyusun kolom 1 (5 sampai dengan 10 kekuatan dan kelemahan).

b. Memberi bobot masing-masing faktor dalam kolom 2, mulai dari 1,0 (sangat penting) sampai dengan 0,0 (tidak penting). Faktor-faktor tersebut kemungkinan dapat memberikan dampak terhadap faktor strategis.

c. Menghitung rating (dalam kolom 3) untuk masing-masing faktor dengan memberikan skala mulai dari 4 (outstanding) sampai dengan 1 (poor) berdasarkan pengaruh faktor tersebut terhadap kondisi perusahaan yang bersangkutan. Setiap variabel yang bersifat positif (semua variabel yang masuk kategori kekuatan) diberi nilai mulai dari +1 sampai dengan +4 .

d. Mengalikan bobot pada kolom 2 dengan rating pada kolom 3, untuk memperoleh faktor pembobotan pada kolom 4. Hasilnya nantinya berupa skor pembobotan untuk masing-masing faktor yang nilainya bervariasi mulai dari 4,0 (outstanding) sampai dengan 1 (poor).

e. Menggunakan kolom 5 untuk memberikan komentar atau catatan mengapa faktor faktor tertentu dipilih dan bagaimana skor pembobotannya dihitung.

f. Menjumlahkan skor pembobotan pada kolom 4, untuk memperoleh total skor pembobotan pada perusahaan yang bersangkutan. Nilai total ini menunjukkan bagaimana perusahaan tertentu bereaksi terhadap faktor-faktor strategis internalnya.

\section{Analisis SWOT}

Tahapan dalam perumusan strategi pengembangan usaha ubi kayu setelah dilakukan analisis matriks EFAS dan IFAS adalah memetakan hasil analisis ke dalam kuadran SWOT yang dapat dilihat pada gambar.

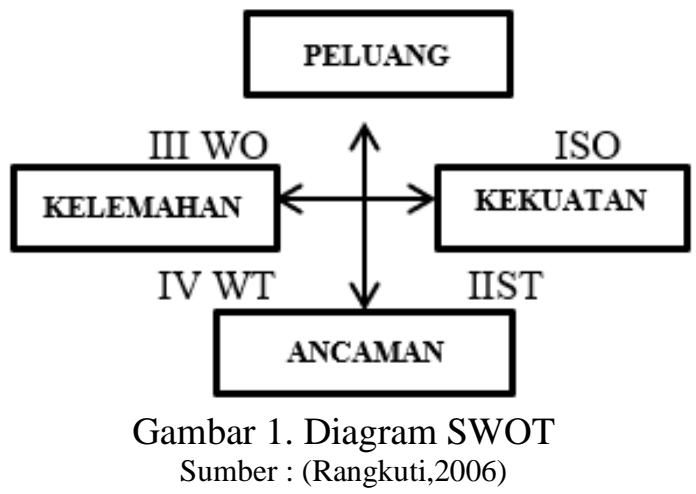

Kuadran I : Ini merupakan situasi yang menguntungkan. Perusahaan tersebut memiliki peluang dan kekuatan sehingga dapat memanfaatkan peluang yang ada. Strategi yang diterapkan dalam kondisi ini adalah mendukung kebijakan pertumbuhan yang agresif.

Kuadran II : Meskipun menghadapi berbagai ancaman, perusahaan ini masih memiliki kekuatan dari segi internal. strategi yang harus diterapkan adalah menggunakan kekuatan untuk memanfaatkan peluang jangka panjang dengan cara strategi diversifikasi (produk/jasa).

Kuadran III : Perusahaan menghadapi peluang pasar yang sangat besar, tetapi dilain pihak menghadapi beberapa kendala/kelemahan internal. Fokus strategi ini yaitu meminimalkan masalah internal perusahaan sehingga dapat merebut pasar yang lebih baik (turn around).

Kuadran IV : Perusahaan mempunyai situasi yang sangat tidak menguntungkan, perusahaan tersebut menghadapi berbagai 
ancaman dan kelemahan internal. Fokus strategi yaitu melakukan tindakan penyelamatan agar terlepas dari kerugian yang lebih besar (defensive).

\section{HASIL DAN PEMBAHASAN}

\section{Karakteristik Petani dan Pedagang Ubi Kayu}

Karakteristik petani dan pedagang dapat diamati dari beberapa variabel yang memungkinkan memberikan gambaran tentang pengelolaan usaha. Karakteristik petani dan pedagang meliputi : umur, tingkat pendidikan, pengalaman berusaha, dan jumlah tanggungan keluarga. Untuk lebih jelas mengenai karateristik petani dan pedagang ubi kayu sebagai berikut:

\section{Umur}

Umur dapat dijadikan sebagai indikator untuk menentukan produktif atau tidaknya seseorang. Umur juga merupakan salah satu faktor yang mempengaruhi petani dalam mengelola usahatani, kemampuan fisik, pola pikir dalam bekerja serta bisa menerima dan mengadopsi inovasi.

Berdasarkan data dapat diketahui bahwa jumlah petani yaitu sebanyak 31 orang. Usia petani ubi kayu di Kelurahan Balai Raja masih tergolong produktif. Dari 31 responden di atas usia petani masih bisa dikatakan produktif, karena usia petani berkisar diantara umur 2160 tahun. Rata- rata umur petani ubi kayu adalah 39 tahun (Lampiran 1). Dengan usia petani yang masih produktif maka kemungkinkan daerah tersebut akan berkembang. Sebab petani yang usianya produktif cendrung lebih mudah menerima informasi maupun inovasi baru serta tenaga yang masih cukup kuat untuk bekerja dan lebih cepat mengambil keputusan ketika menentukan teknologi dalam usaha taninya.

Umur responden pedagang ubi kayu di Kelurahan Balai Raja Kecamatan Pinggir termasuk masih umur produktif antara 31-50 tahun. Rata-rata umur pedagang ubi kayu adalah 45,25 tahun ( Lampiran 2). Dengan umur yang produktif pedagang masih mampu bekerja dengan baik serta didukung dengan fisik yang kuat dan mental yang kuat ketika melaksakan peran sebagai penyalur pemasaran ubi kayu dari petani ataupun produsen ke konsumen. Selain itu pedagang besar yang usianya produktif masih dapat melakukan pengelolaan dan pendistribusian usaha ubi kayu dengan lebih mudah dan melakukan pemasaran ubi kayu dengan cepat.

\section{Tingkat Pendidikan}

Tingginya rata-rata tingkat pendidikan masyarakat sangat perlu bagi persiapan bangsa menghadapi masalah global dimasa depan. Serta pendidikan yang lebih tinggi sangat memudahkan seseorang ataupun masyarakat untuk memperoleh informasi serta menerapkan dalam perilaku serta gaya hidup sehari-hari, khususnya dalam hal kesehatan. Tingkat pendidikan formal bagi seseorang bisa membentuk nilai ketika dalam menerima hal baru (Suhardjo, 2007).

Hasil data dapat dilihat sebagian besar petani yaitu tamatan SMP/MTS sebanyak 15 orang atau 48,38\%. Rata-rata tingkat pendidikan petani adalah 9 tahun. Maka dengan demikian tingkat pendidikan petani di Kelurahan Balai Raja Kecamatan Pinggir dikatakan tergolong cukup rendah karena dari kebanyakan pekerja petani masih banyak yang berpendidikan ditingkat SMP/MTS. Dengan diperoleh adanya pendidikan diharapkan bisa untuk lebih mudah petani untuk menjalankan usaha, serta memperhatikan situasi pasar agar memperoleh keuntungan sebesar-besarnya.

Tingkat pendidikan pedagang ubi kayu yaitu SMA/SMK sebanyak 4 orang (100\%). Rata-rata tingkat pendidikan pedagang adalah 12 tahun. Tingkat pendidikan pedagang ini akan mempengaruhi terhadap pola pikir pedagang besar dalam mengkaji kebutuhan pasar yang berkaitan dengan proses pola pasar sehingga dapat meningkatkan keuntungan pedagang.

\section{Pengalaman Berusahatani dan Pengalaman Berdagang}

Pengalaman seseorang dalam berusahatani berpengaruh dalam kemampuannya menerima inovasi dari luar, pengusaha yang sudah lama berusahatani akan lebih mudah menerapkan masukan-masukan atau anjuran yang diberikan dalam penyuluhan dan demikian pila dengan penerapan teknologi ( Soekartawi, 2003).

Dari data dapat diketahui bahwa pengalaman petani ubi kayu di Kelurahan Balai Raja Kecamatan Pinggir selama 1-2 tahun sebanyak 7 orang, 3-4 tahun sebanyak 13 orang dan 5-6 tahun sebanyak 11 orang. Ratarata pengalaman berusahatani yaitu 4 tahun. 
Pengalaman usaha tani ubi kayu tersebut dapat menunjukkan lamanya waktu petani dalam mengusahakan ubi kayu dalam hal membudidayakan usaha ubi kayu. Dengan pengalaman yang dimiliki oleh petani ubi kayu diharapkan kedepannya mampu lebih baik lagi dalam menjalankan usaha ubi kayu, sehingga dapat mempertahankan kualitas ubi kayu serta dapat meningkatkan skala usaha dan mampu meningkatkatkan usahanya.

Pengalaman berdagang merupakan salah satu hal yang mempengaruhi kemampuan pengusaha dalam menjalankan dan mengelola usaha dagang nya dengan hasil yang optimal, karena jika seseorang memiliki cukup pengalaman maka akan semakin mahir pula dalam mengambil keputusan dan pertimbangan dalam berdagang.

Berdasarkan dat dapat dilihat lamanya usaha pedagang ubi kayu di Kelurahan Balai Raja Kecamatan Pinggir berkisar antara 3-6 tahun. Rata-rata pengalaman pedagang yaitu 5 tahun akan mempengaruhi pengalaman pedagang dalam memasarkan ubi kaayu. Sehingga semakin lama pengalaman berdagang semakin mudah bagi pedagang ketika memasarkan produksi ubi kayu, karena pedagang sudah cukup dikenali oleh konsumen sehingga mempunyai pelanggan ataupun pembeli tetap.

\section{Jumlah Tanggungan Keluarga}

Besarnya jumlah tanggungan keluarga akan dapat mempengaruhi terhadap pendapatan, karena semakin banyak tanggungan keluarga atau jumlah anggota keluarga yang ikut makan maka secara tidak langsung akan memaksa tenaga kerja tersebut untuk mencari tambahan pendapatan (Wirosuhardjo, 1996).

Berdasarkan data dapat diketahu bahwa jumlah tanggungan keluarga petani ubi kayu di Kelurahan Balai Raja Kecamatan Pinggir yaitu jumlah tanggungan 1-2 orang sebanyak 5 orang petani, jumlah tanggungan 3-4 orang sebanyak 24 orang petani dan jumlah tanggungan 5-6 orang sebanyak 2 orang petani. Rata-rata jumlah tanggungan petani yaitu 3 orang. Sehingga semakin banyak jumlah tanggungan maka petani banyak melakukan aktivitas dalam mencari pendapatan untuk keluarganya. Akan tetapi dengan banyaknya jumlah tanggungan maka biaya yang dikeluarkan akan menjadi besar.
Jumlah tanggungan pedagang di Kelurahan Balairaja Kecamatan Pinggir Kabupaten Bengkalis yaitu diantara $2-3$ sebanyak 2 orang pedagang dan $4-5$ sebanyak 2 orang pedagang. Rata-rata jumlah tanggungan pedagang yaitu 3 orang (Lampiran 2). Semakin banyak jumlah tanggungan pedagang maka semakin banyak pula pedagang tersebut mengeluarkan biaya. Namun dengan banyaknya jumlah tanggungan maka pedagang bisa mendapatkan banyak bantuan tenaga kerja dalam keluarganya.

\section{Saluran pemasaran}

Berdasarkan hasil penelitian yang sudah dilaksanakan dapat diketahui mengenai pola pemasaran ubi kayu di Kelurahan Balai Raja Kecamatan Pinggir Kabupaten Bengkalis. Untuk mengetahui saluran pemasaran ubi kayu yang digunakan, diperoleh dengan cara penelusuran jalur pemasaran ubi kayu mulai dari petani sampai ke konsumen akhir. Berdasarkan penelitian yang sudah dilaksanakan pada pemasaran ubi kayu di Kelurahan Balai Raja Kecamatan Pinggir Kabupaten Bengkalis terdapat hanya satu saluran pemasaran yaitu: Petani - Pedagang Pabrik Tapioka

Petani menjual ubi kayu ke pedagang yang mana dalam penjualan ubi kayu pedagang langsung menjemput ubi kayu di kebun petani kemudian pedagang menjual ubi kayu ke pabrik untuk di olah menjadi tepung tapioka Jarak antara pedagang dan kebun petani berkisar 1-2 km. Sedangkan pedagang menjual ubi kayu yang didapati dari petani ke pabrik yang berada di petapahan kabupaten kampar dengan jarak tempuh berkisar $80 \mathrm{~km}$.

Diketahui bahwa petani yang menjual ubi kayu sebanyak 31 orang kepada pedagang . Hal ini menunjukkan bahwa di Kelurahan Balai Raja Kecamatan Pinggir Kabupaten Bengkalis hanya terdapat satu pola pemasaran ubi kayu dan terbatasnya pedagang ubi kayu.

\section{Biaya Pemasaran, Margin Pemasaran, Keuntungan Pemasaran, Farmer's Share, Efisiensi Pemasaran}

Proses mengalirnya produk dari produsen ke konsumen memerlukan suatu biaya, dengan adanya biaya suatu pemasaran maka akan meningkatkan harga suatu produk. Untuk mengetahui besarnya biaya pemaran, margin pemasaran, keuntungan pemasaran, farmer's share dan efisiensi pemasaran ditingkat lembaga pemasaran di saluran yang 
digunakan petani ubi kayu di Kelurahan Balai Raja Kecamatan Pinggir Kabupaten Bengkalis. Bisa dilihat pada tabel dibawah ini.

Tabel 2. Rata-Rata Biaya, Margin Pemasaran, Farmer's Share, Efisiensi Pemasaran Ubi Kayu di Kelurahan Balai Raja Kecamatan Pinggir

\begin{tabular}{clcc}
\hline No & \multicolumn{1}{c}{ Uraian } & Nilai $(\mathrm{Rp} / \mathrm{Kg})$ & Market Share (\%) \\
\hline 1 & Petani Ubi Kayu & 600 & 75 \\
& a. Harga Tingkat Petani & 150 & \\
& b. Biaya Tenaga Kerja & 0 & \\
& c. Biaya Traansportasi & 150 & \\
& d. Total Biaya & & \\
\hline 2 & Pedagang Ubi Kayu & 600 & \\
& a. Harga Beli Ubi Kayu & 0 & \\
& b. Biaya Tenaga Kerja & 100 & 100 \\
& c. Biaya Transportasi & 15 & 5,62 \\
& d. Biaya Muat Ubi Kayu & 40 & \\
& e. Penyusutan Ubi Kayu 5\% & 800 & \\
& f. Harga Jual Ubi Kayu & 45 & 75 \\
e. Keuntungan & 200 & 19,37 \\
\hline 3 & a. Total Marjin Pemasaran & 155 & \\
& b. Total Biaya Pemasaran & & \\
& c. Farmer's Share & & \\
d. Total Efisiensi & &
\end{tabular}

\section{Biaya pemasaran}

Proses pemasaran ubi kayu sangat berhubungan dengan pembiayaan meliputi semua biaya yang terjadi hingga sampai ketangan konsumen. Berdasarkan tabel 14 diatas dapat diketahui bahwa harga jual petani ke pedagang yaitu Rp 600 per $\mathrm{kg}$, adapun biaya yang dikeluarkan petani adalah biaya untuk tenaga kerja biaya yang dikeluarkan petani sejumlah Rp 150 per kg untuk mencabut ubi kayu sekalian dikumpulkan pada satu tempat sedangkan biaya transportasi tidak ada sebab pedagang besar langsung menjemput kelapangan.

Sedangkan pedagang ubi kayu menjual ubi kayu dengan harga jual yaitu Rp 800 per $\mathrm{kg}$, adapun biaya yang dikeluarjan pedagang ubi kayu adalah biaya untuk tenaga kerja yaitu biaya untuk muat ubi kayu sebesar Rp 15 per $\mathrm{kg}$, biaya transportasi sebesar Rp 100 per $\mathrm{kg}$, biaya tersebut dikeluarkan mulai penjemputan ubi ke lahan petani hingga pengantaran ke pabrik ubi kayu, dan pedagang juga mengeluarkan biaya penyusutan ubi kayu sebesar 5\% yaitu Rp 40 per kg dari harga jual $\mathrm{Rp} 800$ per kg tersebut. Maka total biaya yang di keluarkan pedagang ubi kayu untuk memasarkan ubi kayu hingga sampai ke pabrik ubi kayu yaitu Rp 155 per kg

\section{Marjin pemasaran}

Marjin pemasaran merupakan harga selisih yang diterima oleh petani (Produsen) dengan harga yang diberikan oleh konsumen. Berdasarkan tabel $14 \mathrm{di}$ atas marjin yang di dapat pedagang yaitu $\mathrm{Rp} 200$ per $\mathrm{kg}$, marjin tersebut di dapat pedagang dari selisih harga beli pedagang ke petani Rp 600 per kg dengan harga jual pedagang ke pabrik ubi kayu Rp 800 per kg (konsumen).

\section{Keuntungan Pemasaran}

Keuntungan merupakan selisih antara margin dan biaya yang dikeluarkan untuk memasarkan ubi kayu. Berdasarkan tabel 14 di atas total keuntung yang di peroleh pedagang ubi kayu sebesar $\mathrm{Rp} 45$ per $\mathrm{kg}$, total keuntungan di dapatkan dari harga jual pedagang di kurangi dengan biaya pemasaran pedagang. Artinya dalam kegiatan pemasaran ini pedagang ubi kayu masih memiliki keuntungan namun keuntungan yang di dapat masih sedikit, maka perlu dilakukan peningkatan produksi serta perluasan pasar agar keuntungan meningkat.

\section{Farmer's share}

Farmer's share adalah perbandingan antara harga yang diterima oleh petani dengan harga yang dibayarkan oleh konsumen (pabrik) didalam bentuk persentase (\%).

Berdasarkan hasil penelitian pada saluran ini diketahui bahwa nilai Farmer's share nya sebesar $75 \%$. Saluran pemasaran ini tergolong efisien karena nilai Farmer's share nya $>50 \%$ yaitu sebesar $75 \%$. Karena semakin tinggi nilai Farmer's share nya maka akan 
semakin efektif saluran pemasaran yang dilalui suatu produk.

\section{Efisiensi Pemasaran}

Demi kelancaran didalam kegiatan pemasaran barang dari produsen ke konsumen, faktor yang dapat mempengaruhi adalah saluran pemasaran yang efektif dan efisien. Nilai efisiensi pemasaran juga ditengok dengan membedakan nilai efisiensi setiap saluran pemasaran, apabila nilai EP sebuah saluran lebih kecil dibandigkan dengan nilai EP lainnya maka pemasaran tersebut dibilang mempunyai efisiensi pemasaran. Kriteria:

- EP sebesar 0-50\% menghasilkan saluran pemasaran efisien

- EP lebih sebesar dari 50\% menghasilkan pemasaran kurang efisien

Berdasarkan hasil penelitian pada saluran ini diketahui bahwa nilai efisien pemasarannya (EP) yaitu $19,37 \%$. Maka pemasaran pada saluranan ini dikatakan efisien karenan nilai EP nya dibawah $50 \%$. Karena apabila nilai EP nya besar maka pemasaran ini kurang efisien. Nilai EP diperoleh dari total biaya pemasaran dibagi dengan total nilai produk yang dipasarkan. Maka pemasaran ini bisa digunakan karena tergolong efisien maka perlu dilakukan peningkatan produksi nya supaya lebih efektif serta menguntungkan.

\section{Strategi Pengembangan Usaha Ubi Kayu}

Analisis faktor internal pada strategi pengembangan usaha ubi kayu di Kelurahan Balai Raja Kecamatan Pinggir diarahkan untuk mengidentifikasi faktor kekuatan (strength) dan kelemahan (weaknesses). Hasil dari penjumlahan setiap rating, maka dihasilkan pembobotan untuk masing-masing nilai rating faktor internal bahwa faktor koefisisen IFAS kekuatan (strengths) adalah sebesar koefisisen 2,103, adapun koefisien IFAS faktor kelemahan (weaknesses) adalah sebesar 0,786. Hal ini menunjukkan bahwa faktor kekuatan yang dimiliki oleh usaha ubi kayu di Kelurahan Balai Raja Kecamatan Pinggir lebih besar dari pada faktor kelemahan. Ini berarti usaha ubi kayu di Kelurahan Balai Raja Kecamatan Pinggir dapat dimanfaatkan faktorfaktor kekuatan yang dimiliki agar supaya meningkatkan usaha maupun pengembangan yang akan datang serta mengatasi kelemahan yang dimiliki.
Dari hasil perhitungan dari nilai rating serta bobot faktor internal strategi pengembangan usaha ubi kayu di Kelurahan Blai Raja Kecamatan Pinggir didapatkan dari hasil pengurangan dari hasil faktor kekuatan (strength) serta kelemahan (weaknesses) yaitu $2,103-0,786=1,317$ dijadikan sebagai sumbu $\mathrm{X}$, maka sumbu $\mathrm{X}$ dalam diagram SWOT yaitu 1,317 .

Analisis faktor eksternal di strategi pengembangan usaha ubi kayu di Kelurahan Balai Raja Kecamatan Pinggir diarahkan untuk mengidentifikasi faktor peluang (opportunity) serta ancaman (threath). Dari hasil perhitungan setiap rating, maka diperoleh pembobotan untuk masing-masing nilai rating faktor eksternal menunjukkan faktor koefisien EFAS peluang (opportunity) sebesar 2,009, adapun koefisien EFAS faktor ancaman (threath) sebesar 0,899. Hal ini memperlihatkan faktor peluang yang dimanfaatkan oleh usaha ubi kayu di Kelurahan Balai Raja Kecamatan Pinggir lebih besar dari pada faktor ancaman. Ini berarti bahwa usaha ubi kayu di Kelurahan Balai Raja Kecamatan Pinggir telah dimanfaatkan faktor-faktor peluang yang ada supaya dapat terhindar dari ancaman yang bisa mempengaruhi keberhasilan pengembangan usaha ubi kayu di Kelurahan Balai Raja Kecamatan Pinggir.

Dari hasil perhitungan dari nilai rating serta bobot faktor eksternal strategi usaha ubi kayu di Kelurahan Balai Raja Kecamatan Pinggir diperoleh dari hasil pengurangan antara faktor peluang (opportunity) dan ancaman (threath) yaitu 2,009-0,899=1,110 yang dijadikan sebagai sumbu $\mathrm{Y}$, maka sumbu Y dalam diagram SWOT adalah 1,110.

Dari hasil pembobotan faktor internal maupun faktor eksternal bisa disimpulakan total skor yang diperoleh dari pengurangan total faktor kekuatan maupun faktor kelemahan sebagai sumbu $\mathrm{X}$ yaitu sebesar 1,317 sedangkan skor faktor eksternal merupakan hasil pengurangan antara faktor peluang serta faktor ancaman dijadikan sumbu $\mathrm{Y}$ adalah sebesar 1,110 .

Maka bisa diketahui posisi kuadran usaha ubi kayu di Keluraha Balai Raja Keacamatan Pinggir dibuat pada diagram SWOT pada gambar berikut: 
PELUANG

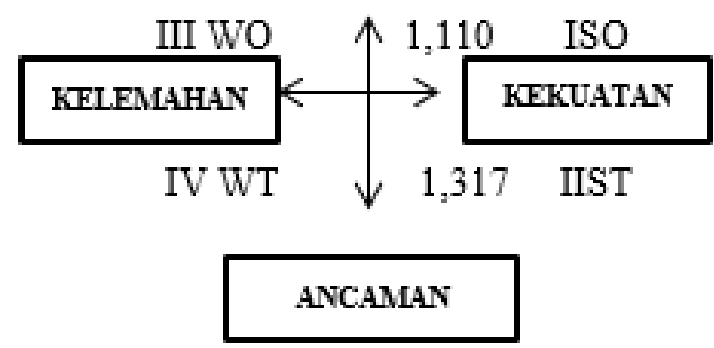

Gambar 2. Hasil Diagram SWOT

Hasil diagram SWOT di atas, posisi usaha pada strategi pengembangan usaha ubi kayu di Kelurahan Balai Raja Kecamatan Pinggir berada di kuadran I, yang mana pada posisi ini suatu usaha memiliki posisi yang kuat serta berpeluang untuk berkembang. Adapun strategi pengembangan usaha ubi kayu dapat dilihat pada matriks SWOT

Dari matriks SWOT dapat diketahui beberapa strategi pengembangan usaha ubi kayu di Kelurahan Balai Raja Kecamatan Pinggir Kabuapten Bengkalis yaitu:

\section{a. Strategi S-O}

Alternatif strategi yang diperoleh berdasarkan strategi $\mathrm{S}-\mathrm{O}$ yaitu adanya lahan, tenaga kerja yang mahir, dan penggunaan bibit ubi kayu yang unggul serta dukungan pemerintah dalam memberikan penyuluhan agar dapat meningkatkan produksi ubi kayu dan perluasan pasar karena adanya perkembangan industri pengolahan ubi kayu.

b. Strategi S-T

Alternatif strategi yang diperoleh mempertahankan tingkat kualitas produksi ubi kayu dan selalu menggunakan bibit ubi kayu yang unggul.

c. Strategi W-O

Alternatif strategi yang diperoleh berdasarkan strategi W-O yaitu pemberian penyuluhan atau pemberian teknologi dari pemerintah agar dapat meningkatkan produksi ubi kayu.

\section{d. Strategi W-T}

Alternatif strategi yang diperoleh berdasarkan strategi W-T yaitu membina hubungan antara petani dan pedagang dengan pemerintah.

\section{KESIMPULAN DAN SARAN}

Berdasarkan penelitian yang telah dilakukan maka dapat disimpulkan sebagai berikut :

1. Karakteristik petani dan pedagang untuk usia masih tergolong produktif, tingkat pendidikan petani tergolong rendah sedangkan untuk pedagang tergolong tinggi, pengalaman berusahatani dan pedagang cukup lama dan jumlah tanggungan tidak banyak.

2. Pemasaran ubi kayu terdapat satu saluran pola pemasaran sebagai berikut : Saluran Pemasaran yaitu Petani - Pedagang Industri Pengolahan Ubi Kayu. Saluran pemasaran ini total biaya pemasaran pedagang besar Rp 155 per kg, keuntungan pemasaran Rp 45 per $\mathrm{kg}$. Jika dilihat dari efisiensi secara ekonomis dari saluran yang ada maka saluran pemasaran ini efisien karena nilai farmer's sharenya di atas 50\% dan nilai EP di bawah 50\%

3. Hasil analisis strategi pengembangan usaha tani ubi kayu di Kelurahan Balai Raja Kecamatan Pinggir Kabupaten Bengkalis berada pada kuadran 1, yaitu strategi S-O Alternatif strategi yang diperoleh berdasarkan strategi S-O yaitu Tersedianya lahan dan tenaga kerja yang mahir maka bisa memenuhi permintaan produksi ubi kayu yang meningkat, dengan menggunakan bibit kayu unggul dan dukungan pemerintah dalam memberikan penyuluhan usaha ubi kayu maka bisa dilakukan perluasan pasar karena adanya perkembangan industri pengolah ubi kayu.

\section{Saran}

Berdasarkan hasil penelitian yang telah dilakukan, maka dapat disarankan hal-hal sebagai berikut :

1. Diharapkan petani mengikuti penyuluhan yang diadakan pemerintah seperti bimbingan teknis (bimtek) dalam mengelola usaha ubi kayu agar bisa menerapkan teknologi pada saat ini karena pendidikan petani rata-rata rendah.

2. Untuk saluran pemasaran diharapkan petani dan pedagang bisa mengolah ubi kayu dalam bentuk olahan lain agar nilai jual ubi kayu meningkat dan pendapatan petani dan pedagang meningkat, serta kebijakan pemerintah dalam membangun industri pengolahan ubi kayu diwilayah 
tersebut karena pabrik ubi kayu di Riau hanya ada satu sehingga kapasitas pembelian ubi kayu terbatas.

3. Strategi pengembangan yang perlu di perhatikan yaitu selalu membina hungungan antara petani dan pedagang dengan pemerintah agar bisa mengatasi kelemahan serta ancaman yang di hadapi nanti nya.

\section{DAFTAR PUSTAKA}

BPS. 2016. Produk Domestik Bruto Indonesia Triwulan 2012- 2016. Jakarta.

Djalil Majeni, Sulaeman. 2015. Strategi Pengembangan Usaha Keripik Ubi Kayu Pada Industri Pundi Mas di Kota Palu. Jurnal Agrotekbis 3(3) : 390-401.

Hasyi A. 2012. Tataniaga Pertanian (Diktat Kuliah). Fakultas Pertanian Universitas Lampung. Bandar Lampung.

Hasyim, H. 2006. Analisis Hubungan Karakteristik Petani Kopi terhadap pendapatan (Studi Kasus: Desa Dolok Saribu Kecamatan Paguran Tapanuli Utara ). Jurnal Komunikasi Penelitian,18.(1) : 22-27.

Hernanto,F. 1991. Ilmu Usahatani. Swadaya. Jakarta.

Hutagaol. 2009. Analisis Multivariate lanjutan dengan program SPSS. Pustaka. Jakarta.

Indra Wijaya, Perilaku Organisasi, (Bandung : Sinar Baru, 1989), 244.

Islami, T. 2015. Ubi Kayu. Bandung. Graha Ilmu

Jatmiko, R. 2003. Manajemen Strategis. UMM Press. Malang.

Kotler. P. 2002. Manajemen Pemasaran, Analisis Pemasaran Kontrol Jilid I. Penerbit PT. Prenhallindo, Jakarta. 330

Kotler.P. 2004. Prinsip-Prinsip Pemasaran. Erlangga. Jakarta.

Limbong. 2010. Pengantar Tataniaga Pertanian. Bogor : Institut Pertanian Bogor, Jurusan Ilmu-Ilmu Sosial Ekonomi Pertanian, Fakultas Pertanian.

Listiyani. 2001. Analisis Penawaran Ubi Kayu di Kabupaten Gunung Kidul. Jurnal Dinamika Sosial Ekonomi, 2.(2) : 39-40.

Maulita, Dwi. 2019. Analisis Nilai Tambah Dan Strategi Pengembangan Agroindustri Tepung Tapioka X di Kecamatan Kalirejo Kabupaten Lampung Tengah (Studi Kasus : di Kecamatan Kalirejon Kabupaten
Lampung Tengah). Skripsi. Fakultas Pertanian Universitas Lampung.

Mubyarto. 1998. Pengantar Ekonomi Pertanian. LP3ES. Jakarta.

Muhaimin Wahib Abdul, Ratna Prawiyanti. 2010. Strategi Pengembangan Agroindustri Tapioka Pada Skala Usaha Kecil. AGRISE Volume 10 (3) : 191202

Muhammad Haydar. 2011. Word Press. Online pada: https://muhammadhaydar. wordpress.com/20011/02/02/tafsir-ashshaf-ayat-10-13/. Diakses tanggal 8 juni 2021.

Mkita Solo. 2011. Blogspot. Online pada: https://mkitasolo.blogspot.com /2011/12/tafsir-suratnisa4ayat29.html? $\mathrm{m}=1$. Diakses tanggal 8 juni 2021.

Mulyadi. 2005. Akutasi Biaya. Edisi Kelima. UUP STIKM YKPN. Yogyakarta.

M. Yogi Syahputra. 2019. Analisis Pemasaran Ubi Kayu Rakyat ( Studi Kasus : Desa Jaharun B, Kecamatan Galang, Kabupaten Deli Serdang). Skripsi. Fakultas Pertanian Universitas Muhammadiyah Sumatra Utara.

Prabowo Bakti Hari Wayan I, dkk. 2015. Strategi Pengembangan Usahatani Ubi Kayu (Manihot utilissima) di Kecamatan Menggala Kabupaten Tulang Bawang. JIIA Volume 3 (1) : 48-56

Purnamasari, Indah. 2018. Analisis Pemasaran Ubi Kayu di Kecamatan Bandar Mataram Kabupaten Lampung Tengah. Skripsi. Universitas Lampung. Bandar Lampung.

Purwanto Joko Mahkruf, dkk. 2016. Strategi Pengembangan Budidaya Kentang (Solanum Tuberosum L) di Kecamatan Ngablak Kabupaten Mangelang. SEPA Volume 13 (1) : 53-62.

Pusat Data dan Sistem Informasi Pertanian Kementerian Pertanian. 2015. Outlook Ubi Kayu. Kementerian Pertanian. Jakarta.

Rahim, A dan Hastuti, D.R.D. 2008. Sistem Manajemen Agribisnis. Penebar Swadaya. Jakarta.

Rangkuti, 2001. Analisis SWOT Teknik Membedah Kasus Bisnis. Gramedia, Jakarta.

Rukman, Rahmad. 1997. Ubi Kayu, Budidaya dan Pascapanen. Kanisius, Yogyakarta. 
Soekartawi. 2002. Analisis UsahaTani. Universitas Indonesia Press. Jakarta.

Soekartawi. 1995. Analisis Usaha Tani. Universitas Indonesia. Jakarta.

Sudiyono dan Armand. 2002. Pemasaran Pertanian. UMM Press. Malang

Untari, dkk. 2018. Identifikasi Saluran dan Perilaku Lembaga Pemasaran Singkong di Kabupaten Merauke. International Journal Of Civil Engineering And Technology (IJCIET). Vol.9 (12) : 261266.
W.J.S. Poerwadarminta, Kamus Umum Bahasa Indonesia, PN. Balai Pustaka, Jakarta 2009, hal .721.

Zuhry Salman, dkk. 2012. Strategi Pengembangan Ubi Kayu di Kabupaten Serdang Bedagi. Jurnal Agribisnis Sumatra Utara. Vol.5 (1) : 17-27 